\title{
E-Ticketing System and Integration with Third Parties Scrum-Based
}

\author{
Jimmy Sentosa ${ }^{1}$ \\ Study Program \\ Technical Information \\ STIMIK Likmi \\ Email: sentosa.jimmy@yahoo.com
}

\author{
Maharina ${ }^{2}$ \\ Study Program \\ Technical Information \\ STIMIK Likmi \\ Email: maharina@gmail.com
}

\author{
Candra Zonyfar ${ }^{3}$ \\ Study Program \\ Technical Information \\ Universitas Buana Perjuangan Karawang \\ Email: candra@ubpkarawang.ac.id
}

Abstract-SCRUM is a software development life cycle that will work with collaboration to produce products quickly but still provide quality. By using SCRUM, it will increase productivity and increase mutual trust, togetherness, responsibility, ideas communication and creativity of team members. The stakeholder's expectation to build an e-ticketing system fits with the agile nature of SCRUM. Every process in SCRUM must run well starting from data collection, needs analysis, making product backlog, making sprint backlog, daily scrum meeting, sprint review until sprint retrospective must be carried out to achieve success. The applications built in this research will run on web browsers, android and API designs to be integrated with other applications. The research was conducted for two months by working on three product backlogs, then each product backlog would be broken down into three sprints. The results obtained in the study were able to answer the question of the problem that was built with the conclusion that the product owner's ability to communicate with stakeholders and daily scrum meetings was necessary in determining success in SCRUM.

Keywords - e-ticketing, Sinar Jaya, SCRUM, API, mobile, floor plan, seats, analysis, Traveloka, redbus

Abstrak- SCRUM merupakan siklus hidup pengembangan perangkat lunak yang akan bekerja dengan kolaborasi untuk menghasilkan produk dengan cepat namun tetap memberikan kualitas. Dengan menggunakan SCRUM akan meningkatkan produktivitas dan meningkatkan rasa saling percaya, kebersamaan, tanggung jawab, komunikasi ide dan kreativitas anggota tim. Harapan pemangku kepentingan untuk membangun sistem e-ticketing sesuai dengan sifat gesit SCRUM. Setiap proses dalam SCRUM harus berjalan dengan baik mulai dari pengumpulan data, analisis kebutuhan, pembuatan product backlog, pembuatan sprint backlog, daily scrum meeting, sprint review hingga sprint retrospective harus dilakukan untuk mencapai kesuksesan. Aplikasi yang dibangun pada penelitian ini akan berjalan pada web browser, android dan desain API untuk diintegrasikan dengan aplikasi lain. Penelitian dilakukan selama dua bulan dengan mengerjakan tiga product backlog, kemudian setiap product backlog akan dipecah menjadi tiga sprint. Hasil yang diperoleh dalam penelitian mampu menjawab pertanyaan dari permasalahan yang dibangun dengan kesimpulan bahwa kemampuan product owner untuk berkomunikasi dengan stakeholders dan pertemuan scrum harian sangat diperlukan dalam menentukan keberhasilan dalam SCRUM.

Kata kunci-e-ticketing, Sinar Jaya, SCRUM, API, mobile, denah lantai, kursi, analisis, Traveloka, redbus.

\section{INTRODUCTION}

Information technology growing rapidly parallel with the development of internet. Indonesian government make some regulation for encourage companies to follow technology. Regulation Department Of Transportation Republic Of Indonesia Number Pm 15 Year 2019 informs every transportation company to issue electronic tickets and passenger manifests. Based on these regulations, each transportation company must have its own e-ticketing system or can cooperate with existing e-ticketing systems such as tiketux.com.

PT. Sinar Jaya Megah Langgeng is a transportation company that prioritizes long trayek from city to city or island to island in Indonesia. PT. Sinar Jaya Megah Langgeng has 36 years of experience and is one of the biggest companies in the transportation sector. PT. Sinar Jaya Megah Langgeng has many agents from Lampung to Sampang Madura. PT. Sinar Jaya Megah Langgeng requires an e-ticketing information system starting from ticket sales to agent deposits. There are a lot of fictitious sales reports or ticket pricing outside the predetermined limits. The information system built is expected to minimize fraud in the field.

In this research also will design about API e-ticketing for collaborating with third party agents such as Traveloka and Redbus. E-ticketing system will use SCRUM method because of the needs of PT. Sinar Jaya Megah Langgeng who wants to create an e-ticketing system in a short time due to demands from the government. SCRUM is considered to be able to fulfill the request of PT. Sinar Jaya Megah Langgeng because of its agile and fast nature. In addition, the development team needs 9 people and have expertise in their respective fields according to the needs of SCRUM. Rapid project development requires continuous inspections that can be analyzed through daily scrum meetings. Based on this, SCRUM is considered to be the most feasible method compared to other software development methods.

The following are research about ticketing system that have been previously written which have similarities and became a reference in the preparation of this study. From previous search there not have any discussion about ticket sales by displaying mockups of seats. Seat mockups are needed so that passengers know the desired seat location. 


\begin{tabular}{|c|c|}
\hline Writer & Result of research \\
\hline $\begin{array}{l}\text { Naila, Ajith dan } \\
\text { Muhammad } \\
\text { Murshid M.A. } \\
\text { [11] }\end{array}$ & $\begin{array}{l}\text { The system created does not issue physical tickets and } \\
\text { manifests. All transactions are recorded in the } \\
\text { application and the conductor must scan the qrcode } \\
\text { present in the application as proof of the passenger } \\
\text { manifest. }\end{array}$ \\
\hline Wahyudi [21] & $\begin{array}{l}\text { The method used in system development is the } \\
\text { waterfall method. Does not issue physical tickets and } \\
\text { does not explain about ticket redemption because it is a } \\
\text { case study for the concert seat system and there is no } \\
\text { manifest. }\end{array}$ \\
\hline $\begin{array}{l}\text { Neli Nailul } \\
\text { Wardah [22] }\end{array}$ & $\begin{array}{l}\text { The method used in system development is the } \\
\text { waterfall method. And the system created does not } \\
\text { issue physical tickets and manifests, all transactions are } \\
\text { carried out via the web. }\end{array}$ \\
\hline $\begin{array}{l}\text { Della Fauziah, } \\
\text { Fajar Pradana, } \\
\text { Achmad Arwan } \\
\text { [3] }\end{array}$ & $\begin{array}{l}\text { The method used in system development is the } \\
\text { waterfall method. The study did not go into more detail } \\
\text { about ticket sales. The research discusses algorithms in } \\
\text { finding route optimization. }\end{array}$ \\
\hline Oky Septian [18] & $\begin{array}{l}\text { The method used is the waterfall method. No physical } \\
\text { tickets are issued as all transactions use the app. Not } \\
\text { discussing ticket exchange. }\end{array}$ \\
\hline $\begin{array}{l}\text { I Gede Totok } \\
\text { Suryawan dan } \\
\text { Ary Wira } \\
\text { Andika [19] }\end{array}$ & $\begin{array}{l}\text { The method used is the SCRUM method using } 7 \\
\text { sprints. The application built is not an e-ticketing } \\
\text { application but is similar to reservation and booking } \\
\text { for tour vehicles. }\end{array}$ \\
\hline $\begin{array}{l}\text { Bienderil and } \\
\text { Achmad Kodar } \\
{[5]}\end{array}$ & $\begin{array}{l}\text { The method used is the SCRUM method using } 13 \\
\text { sprints. The application built is not an e-ticketing } \\
\text { application but a reservation for massage services }\end{array}$ \\
\hline $\begin{array}{l}\text { Ahmed Ibrahim } \\
\text { dan Azman B } \\
\text { Ta'a[4] }\end{array}$ & $\begin{array}{l}\text { The method used is the prototyping method using the } \\
\text { Phonegap Framework. There is no seating sketch } \\
\text { display when booking tickets. }\end{array}$ \\
\hline $\begin{array}{l}\text { Oloyede, M.O, } \\
\text { Alaya S.M dan } \\
\text { Alaya S.M [12] }\end{array}$ & $\begin{array}{l}\text { The research does not discuss the system development } \\
\text { method and only discusses ticket bookings without a } \\
\text { schedule or seat availability. }\end{array}$ \\
\hline
\end{tabular}

\section{METHOD}

\section{A. Software Development Life Cycle (SDLC)}

SDLC is a process of designing a system that always moves like a wheel that goes through steps such as planning, analysis, design, implementation, and maintenance. Then the system will return to the planning stage if it is deemed inefficient to implement [9].

\section{B. Agile}

Agile is a collaborative technique between an iterative and evolutionary approach by using documents formal form in relation to building software that is of good quality in terms of cost and at the right time according to changing needs [15].

\section{SCRUM}

SCRUM is a system development method technique that was first created by Jeff Sutherland in 1993. SCRUM is a framework or methodology for developing product management and is a work pattern where everyone in the team is faced with ways to solve complex adaptive problems and at the same time being challenged to create products with the highest value productively and creatively [20].

SCRUM also is a methodology that follows an Agile approach or principles. SCRUM is a framework of responsive software development for product management or application development that focuses on strategy, flexible product development where a team works and is divided into units to achieve common goals [13]. SCRUM is based on empirical process control theory or empiricism that is Transparency, Inspection, and Adaption [17].

\section{Scrum Flows}

SCRUM has complex stages that can affect the final result of system development. The stages in SCRUM are as follows product owner create product backlog, then product owner and scrum master will create sprint planning based on product backlog. Every member in tim scrum then will develop the product called as sprint. The sprint will be closed with a sprint review to see if the sprint was successful or not [13]. To monitor sprint development team must organize daily scrum meeting that has a time limit of 15 minutes. This event is held every day during the sprint. In this event, the development team makes a work plan for the next 24 hours [17].

E. Application Programming Interface (API)

Application Programming Interface or commonly called API is a collection of commands and functions that allow a system to interact with other systems. The API also functions as a bridge to make it easier for developers to use software infrastructure to rebuild the infrastructure [16]. APIs are used to build distributed software systems whose components are interrelated but separate [1].

F. Representional State Transfer

Representational State Transfer or commonly referred to as REST is a form of web standard architecture that uses the HTTP protocol to exchange data. REST is often used in building multiplatform applications using APIs. This is because in addition to having good performance, the use of REST is fast and easy in data exchange and communication [2]. The output of REST common called as JavaScript Object Notation or s JSON which is a format that consists of structured information and is generally used to transmit data between the server and the client [10].

G. E-ticketing

E-ticketing is a way to document the travel process of passengers without issuing ticket papers. All information regarding passenger and travel data is stored digitally [6]. Eticketing is made to make it easier for passengers to book tickets and to help admins and drivers with their daily tasks. The e-ticketing system runs online to make it easier or easier to buy bus tickets or travel information [14]. Eticketing also an application on the web that allows passengers to check seat availability, purchase tickets, and pay for tickets online [11].

\section{RESULTS AND DISCUSSION}

In making the system for PT. Sinar Jaya Megah Langgeng, first a SCRUM team must be formed with roles and tasks performed by the SCRUM team in developing the eticketing system as follows

\section{TABLE 1 SCRUM TEAM ROLE}

\begin{tabular}{|l|l|l|}
\hline Role & Position & Task \\
\hline $\begin{array}{l}\text { Product } \\
\text { Owner }\end{array}$ & $\begin{array}{l}\text { Project } \\
\text { Manager }\end{array}$ & $\begin{array}{l}\text { Receive requests from clients and } \\
\text { make a priority scale on the product } \\
\text { backlog that is made to be carried out } \\
\text { by the SCRUM team, establish good } \\
\text { relationships with stakeholders. }\end{array}$ \\
\hline $\begin{array}{l}\text { Scrum } \\
\text { Master }\end{array}$ & $\begin{array}{l}\text { Scrum } \\
\text { Master } \\
\text { team so that the rules in SCRUM can } \\
\text { be applied during the system } \\
\text { development period and arrange for } \\
\text { the daily scrum meeting to run }\end{array}$ \\
\hline
\end{tabular}




\begin{tabular}{|l|l|l|}
\hline Role & Position & Task \\
\hline $\begin{array}{l}\text { Development } \\
\text { Team }\end{array}$ & $\begin{array}{l}\text { Backend } \\
\text { Developer 1 }\end{array}$ & $\begin{array}{l}\text { Create backend functions for third } \\
\text { party agents }\end{array}$ \\
\hline $\begin{array}{l}\text { Development } \\
\text { Team }\end{array}$ & $\begin{array}{l}\text { Backend } \\
\text { Developer 2 } \\
\text { Team }\end{array}$ & $\begin{array}{l}\text { Creating functions on the backend for } \\
\text { the e-ticketing system }\end{array}$ \\
\hline $\begin{array}{l}\text { Development } \\
\text { Team }\end{array}$ & $\begin{array}{l}\text { Frovelond } \\
\text { Developer 1 } 2\end{array}$ & $\begin{array}{l}\text { Creating a dynamic user interface, } \\
\text { integrating the user interface with the } \\
\text { functions provided by the backend } \\
\text { developer }\end{array}$ \\
\hline $\begin{array}{l}\text { Development } \\
\text { Team }\end{array}$ & $\begin{array}{l}\text { Creating a dynamic user interface, } \\
\text { integrating the user interface with the } \\
\text { functions provided by the backend } \\
\text { developer }\end{array}$ \\
\hline $\begin{array}{l}\text { Development } \\
\text { Team }\end{array}$ & Ueveloper & $\begin{array}{l}\text { Creating user interfaces on mobile and } \\
\text { connecting with functions provided by } \\
\text { backend developers }\end{array}$ \\
\hline $\begin{array}{l}\text { Development } \\
\text { Team }\end{array}$ & $\begin{array}{l}\text { Creating user interfaces on mobile and } \\
\text { connecting with functions provided by } \\
\text { backend developers }\end{array}$ \\
\hline
\end{tabular}

In designing the e-ticketing system at PT. Sinar Jaya Megah Langgeng, the author uses the research method in the picture as follows:

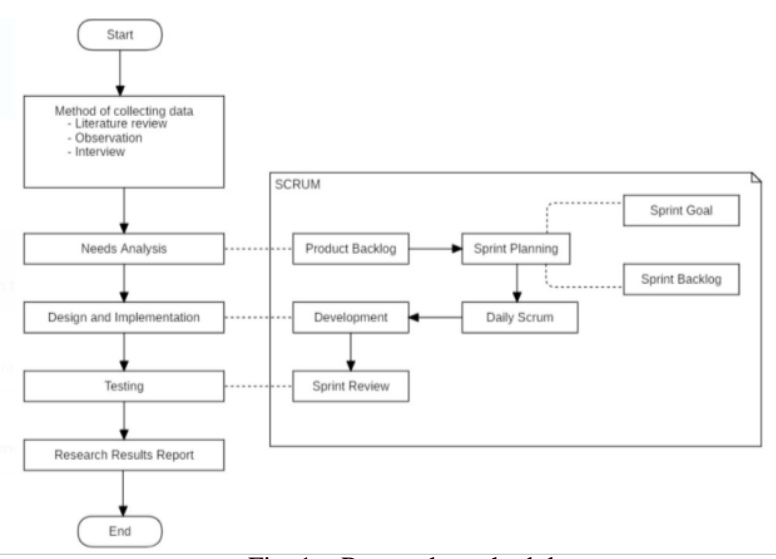

Fig. 1. Research methodology

The e-ticketing system developed aims to create an effective management of ticket sales transactions carried out by agents of PT. Sinar Jaya Megah Langgeng, which previously still made sales transactions using manual tickets. the modules that will be developed are the schedule and departure planning module, the ticket sales module and the deposit module as well as cash inflows.

Each module will be done in 1 product backlog and each product backlog will be done in 1 sprint. Product backlog Departure schedule planning will be carried out for a duration of two weeks with a sprint goal of being able to make a schedule based on the selected filter for one calendar month, Product backlog of ticket sales will be done within one month with the sprint goal API function for third party agents has been completed and sales can operate on android and browsers to printing electronic tickets. Product backlog of deposits and cash inflows will be done within two weeks with a sprint goal of receiving money from agents.

TABLE 2 SPRINT SCHEDULE AND DEPARTURE PLANNING

\begin{tabular}{|l|l|l|l|}
\hline ID & Description & Days & Programmer \\
\hline J01 & Master permission function & 1 & Backend Developer 1 \\
\hline 01 & Master permission view & 1 & Frontend Developer 1 \\
\hline J02 & Master user function & 1 & Backend Developer 1 \\
\hline J02 & Master user view & 1 & Frontend Developer 1 \\
\hline J03 & Login function & 1 & Backend Developer 1 \\
\hline J03 & Login view & 1 & Frontend Developer 1 \\
\hline J04 & Master terminal function & 1 & Backend Developer 2 \\
\hline
\end{tabular}

\begin{tabular}{|l|l|l|l|}
\hline ID & Description & Days & Programmer \\
\hline J04 & Master terminal view & 1 & Frontend Developer 2 \\
\hline J05 & Bus class master function & 1 & Backend Developer 1 \\
\hline J05 & Bus class master view & 1 & Frontend Developer 1 \\
\hline J06 & Bus type master function & 1 & Backend Developer 1 \\
\hline J06 & Bus type master view & 1 & Frontend Developer 1 \\
\hline J07 & Mockup master function & 2 & Backend Developer 2 \\
\hline J07 & Mockup master view & 3 & Frontend Developer 2 \\
\hline J08 & Tripcode master function & 2 & Backend Developer 1 \\
\hline J08 & Tripcode master view & 2 & Frontend Developer 1 \\
\hline J09 & $\begin{array}{l}\text { Departure generate from } \\
\text { tripcode function }\end{array}$ & 3 & Backend Developer 2 \\
\hline J09 & $\begin{array}{l}\text { Departure generate fron } \\
\text { tripcode view }\end{array}$ & 4 & Frontend Developer 2 \\
\hline J10 & $\begin{array}{l}\text { Departure list and update } \\
\text { function }\end{array}$ & 2 & Backend Developer 1 \\
\hline J10 & Departure list and update view & 2 & Frontend Developer 1 \\
\hline J11 & Function for get departure data & 1 & Backend Developer 2 \\
\hline J11 & $\begin{array}{l}\text { Function for export departure } \\
\text { data }\end{array}$ & 2 & Backend Developer 2 \\
\hline J11 & Report loadfactor view & 1 & Frontend Developer 2 \\
\hline Total & 9 & Frontend Developer 1 \\
\cline { 2 - 4 } & & 8 & Frontend Developer 2 \\
\cline { 2 - 4 } & & 9 & Backend Developer 1 \\
\cline { 2 - 4 } & & 9 & Backend Developer 2 \\
\hline
\end{tabular}

Table 3. Sprint Sales

\begin{tabular}{|c|c|c|c|}
\hline ID & Description & Days & Programmer \\
\hline T01 & Price rate master function & 4 & Backend Developer 2 \\
\hline T01 & Price rate master view & 4 & Frontend Developer 2 \\
\hline T02 & Display from access & 3 & Frontend Developer 1 \\
\hline T03 & $\begin{array}{l}\text { Departure schedule for agent } \\
\text { function }\end{array}$ & 2 & Backend Developer 2 \\
\hline T03 & $\begin{array}{l}\text { Departure schedule for agent } \\
\text { view }\end{array}$ & 3 & Frontend Developer 2 \\
\hline T04 & $\begin{array}{l}\text { List available seat plan } \\
\text { function }\end{array}$ & 2 & Backend Developer 2 \\
\hline T04 & $\begin{array}{l}\text { Sketch and list available seat } \\
\text { view }\end{array}$ & 5 & Frontend Developer 2 \\
\hline T05 & $\begin{array}{l}\text { Function to get ticket prices } \\
\text { when there is a combination } \\
\text { of boarding point, drop point } \\
\text { and bus class }\end{array}$ & 3 & Backend Developer 1 \\
\hline T05 & $\begin{array}{l}\text { Display departure information } \\
\text { and prices from search } \\
\text { combinations }\end{array}$ & 3 & Frontend Developer 2 \\
\hline T06 & Functions for sales & 4 & Backend Developer 2 \\
\hline T06 & $\begin{array}{l}\text { Display for sales of spare } \\
\text { tickets and seats }\end{array}$ & 5 & Frontend Developer 2 \\
\hline T07 & Function to get ticket data & 2 & Backend Developer 1 \\
\hline T07 & $\begin{array}{l}\text { Automatic display and print } \\
\text { when opening ticket view }\end{array}$ & 5 & Frontend Developer 1 \\
\hline T08 & $\begin{array}{l}\text { Third party agent master } \\
\text { function }\end{array}$ & 2 & Backend Developer 1 \\
\hline T08 & $\begin{array}{l}\text { Third party agent master } \\
\text { display and menu }\end{array}$ & 3 & Frontend Developer 1 \\
\hline T09 & $\begin{array}{l}\text { Function for departure info } \\
\text { based on parameters sent }\end{array}$ & 2 & Backend Developer 1 \\
\hline T10 & $\begin{array}{l}\text { Function to place order on } \\
\text { API }\end{array}$ & 2 & Backend Developer 2 \\
\hline T11 & $\begin{array}{l}\text { Function to cancel booking } \\
\text { tickets that have expired }\end{array}$ & 2 & Backend Developer 2 \\
\hline T12 & $\begin{array}{l}\text { Function to view seat } \\
\text { availability }\end{array}$ & 2 & Backend Developer 2 \\
\hline T13 & $\begin{array}{l}\text { Function to change order } \\
\text { status if there is a payment } \\
\text { request }\end{array}$ & 2 & Backend Developer 2 \\
\hline T14 & Function to cancel ticket & 3 & Backend Developer 1 \\
\hline T14 & Function to cancel ticket & 8 & Frontend Developer 1 \\
\hline T15 & $\begin{array}{l}\text { Create application with } \\
\text { default browser }\end{array}$ & 6 & Mobile Developer \\
\hline T16 & Bluetooth printer settings & 5 & Mobile Developer \\
\hline T17 & Bluetooth printer settings & 4 & Backend Developer 1 \\
\hline T17 & $\begin{array}{l}\text { Print the printer if the url } \\
\text { contains the word print_ticket }\end{array}$ & 8 & Mobile Developer \\
\hline
\end{tabular}

40 | Vol.2 No.2, July 2021 


\begin{tabular}{|l|l|l|l|}
\hline T18 & Function to get sales data & 2 & Backend Developer 1 \\
\hline T18 & Function to export sales data & 2 & Backend Developer 1 \\
\hline \multirow{4}{*}{ Total } & 19 & Frontend Developer 1 \\
\cline { 3 - 4 } & 20 & Frontend Developer 2 \\
\cline { 3 - 4 } & 20 & Backend Developer 1 \\
\cline { 3 - 4 } & 20 & Backend Developer 2 \\
\cline { 3 - 4 } & 19 & Mobile Developer \\
\hline
\end{tabular}

TABLE 4 DEPOSIT SPRINT AND CASH INFLOW

\begin{tabular}{|c|c|c|c|}
\hline ID & Description & Days & Programmer \\
\hline S01 & Ticket claim function & 2 & Backend Developer 1 \\
\hline S01 & Ticket claim display & 2 & Frontend Developer 1 \\
\hline S02 & $\begin{array}{l}\text { Close sales function and } \\
\text { create manifest }\end{array}$ & 4 & Backend Developer 2 \\
\hline S02 & $\begin{array}{l}\text { Display close sales and } \\
\text { manifest strook }\end{array}$ & 3 & Frontend Developer 2 \\
\hline S03 & Deposit function & 2 & Backend Developer 2 \\
\hline S03 & Agent deposit display & 2 & Frontend Developer 2 \\
\hline S04 & $\begin{array}{l}\text { Function get deposit list for } \\
\text { resume }\end{array}$ & 1 & Backend Developer 1 \\
\hline S04 & $\begin{array}{l}\text { Display of deposits via } \\
\text { resume }\end{array}$ & 3 & Frontend Developer 1 \\
\hline S05 & Function get deposit data & 2 & Backend Developer 1 \\
\hline S05 & $\begin{array}{l}\text { Display of deposit print and } \\
\text { autoprint }\end{array}$ & 3 & Frontend Developer 1 \\
\hline S06 & $\begin{array}{l}\text { Printer format API for } \\
\text { manifest }\end{array}$ & 1 & Backend Developer 1 \\
\hline S06 & $\begin{array}{l}\text { Print manifest if the url } \\
\text { contains the word } \\
\text { print_manifest }\end{array}$ & 5 & Mobile Developer \\
\hline S07 & $\begin{array}{l}\text { Printer format API for } \\
\text { deposits }\end{array}$ & 1 & Backend Developer 1 \\
\hline S07 & $\begin{array}{l}\text { Print the deposit if the url } \\
\text { contains the word } \\
\text { print_setoran }\end{array}$ & 5 & Mobile Developer \\
\hline S08 & $\begin{array}{l}\text { Function to get deposit and } \\
\text { resume data }\end{array}$ & 1 & Backend Developer 1 \\
\hline S08 & $\begin{array}{l}\text { Function to export deposit } \\
\text { and resume data }\end{array}$ & 1 & Backend Developer 1 \\
\hline S08 & $\begin{array}{l}\text { Display for deposit data } \\
\text { reports and resumes }\end{array}$ & 2 & Frontend Developer 2 \\
\hline S09 & $\begin{array}{l}\text { Function to get commission } \\
\text { data }\end{array}$ & 2 & Backend Developer 2 \\
\hline S09 & $\begin{array}{l}\text { Function to export } \\
\text { commission data }\end{array}$ & 2 & Backend Developer 2 \\
\hline S09 & $\begin{array}{l}\text { Display for commission data } \\
\text { report }\end{array}$ & 2 & Frontend Developer 1 \\
\hline S10 & Function to get passenger data & 1 & Backend Developer 1 \\
\hline S10 & $\begin{array}{l}\text { Function to export passenger } \\
\text { data }\end{array}$ & 1 & Backend Developer 1 \\
\hline S10 & $\begin{array}{l}\text { Display for passenger data } \\
\text { reports }\end{array}$ & 2 & Frontend Developer 2 \\
\hline S11 & $\begin{array}{l}\text { Function to get loadfactor } \\
\text { data }\end{array}$ & 1 & Backend Developer 1 \\
\hline S11 & $\begin{array}{l}\text { Function to export loadfactor } \\
\text { data }\end{array}$ & 1 & Backend Developer 1 \\
\hline S11 & $\begin{array}{l}\text { Display for loadfactor data } \\
\text { report }\end{array}$ & 1 & Frontend Developer 2 \\
\hline \multirow{5}{*}{\multicolumn{2}{|c|}{ Total }} & 10 & Frontend Developer 1 \\
\hline & & 10 & Frontend Developer 2 \\
\hline & & 10 & Backend Developer 1 \\
\hline & & 10 & Backend Developer 2 \\
\hline & & 10 & Mobile Developer \\
\hline
\end{tabular}

At this stage the Scrum team begins to create applications based on the sprints that have been set. In the development process using the Trello application to control the tasks that have been done. In Trello, a sprint panel and a develop, checking, need to change, question and discussion, commit and completed panel will be created. programmers can move items in the sprint panel into the develop panel when they are in progress. If the programmer has finished creating a function, then the programmer is obliged to move the finished item into the checking panel to be checked by the tester after deploying the work to the development server. If it passes the check, the tester can move the item to the commit panel.

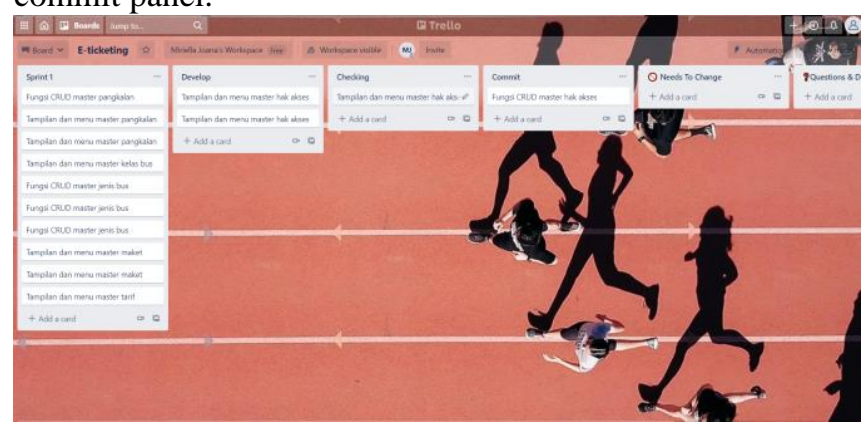

Fig. 2. Trello application

The SCRUM Master is then tasked with deploying the commits to the production server. If it does not pass the check, the tester will enter the item into the needs to change panel and the programmer can move the item to develop to be reworked. A sprint is declared successful if the sprint panel is empty and all items have entered the completed panel. If there are still items hanging, then the sprint will be declared failed. After the sprint is successful, the SCRUM team can repeat the same process on the Sprint 2, Sprint 3 panel. Trello is an option for monitoring work besides being free, Trello can also be viewed via a browser and can contain information, both text, attachments and images. So that the items in the work panel can be fully described in Trello. The flow of the development process can be seen below

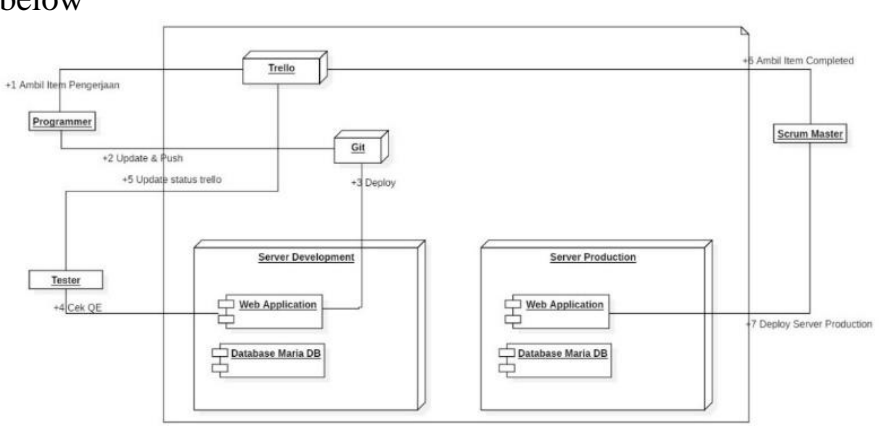

Fig. 3. Development process

The daily scrum meeting process is carried out by holding a meeting using google meet between the SCRUM team and the SCRUM master at $4 \mathrm{pm}$ every day. Meetings are held virtually because WFH is often applied within the company. The duration of the meeting is approximately 15 minutes. The things that were discussed in the meeting were:

1. What has been done on the D day. In this discussion, it can be seen the work carried out by each member of the SCRUM team, whether they meet the deadline in Trello or not, also know what features can be tested by the tester.

2. What obstacles are encountered in the execution of the task. This is intended to provide information to the SCUM master about what obstacles are encountered. The SCRUM master is then tasked with finding ways to minimize the obstacles that occur. The existing constraints are not discussed in detail in the daily scrum meeting because of course it will take time and make the work ineffective. 
3. Questions to be discussed for working on the next day's task. If it can be answered quickly, it will be discussed in the meeting. However, if it is technical and feels time consuming, it will be discussed personally with the SCRUM master.

In a sprint review, everyone on the SCRUM team gets together and discusses the results of the sprint. Users are also invited to take part in a sprint review to discuss what has been completed. From the sprint review, ideas or opinions will usually appear that might add to or adjust existing functions. All opinions will be recorded and may be entered into the next sprint.

The duration of the sprint review can last as long as 3 hours. In the sprint review, Scrum team members will directly provide demos directly through the application or the users themselves who use the application. All features that are completed and can be used according to what the user wants will be recorded as increments.

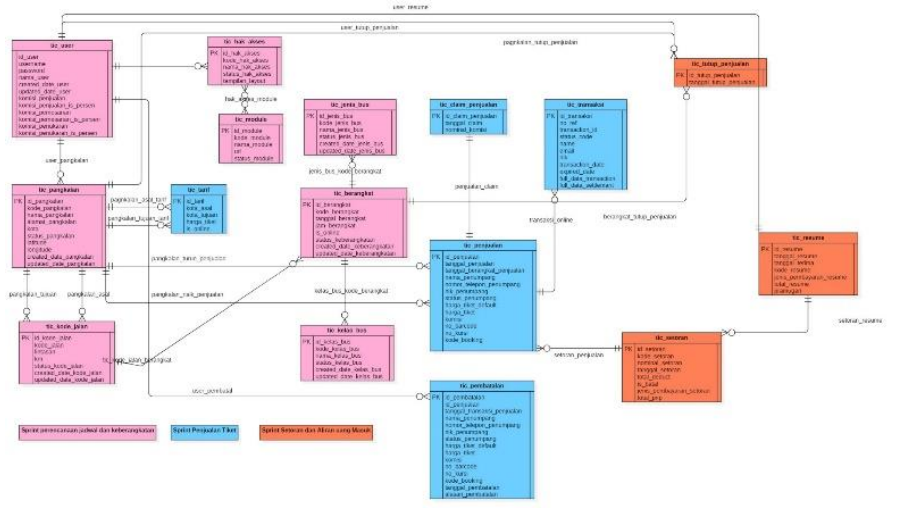

Fig. 4. ERD system
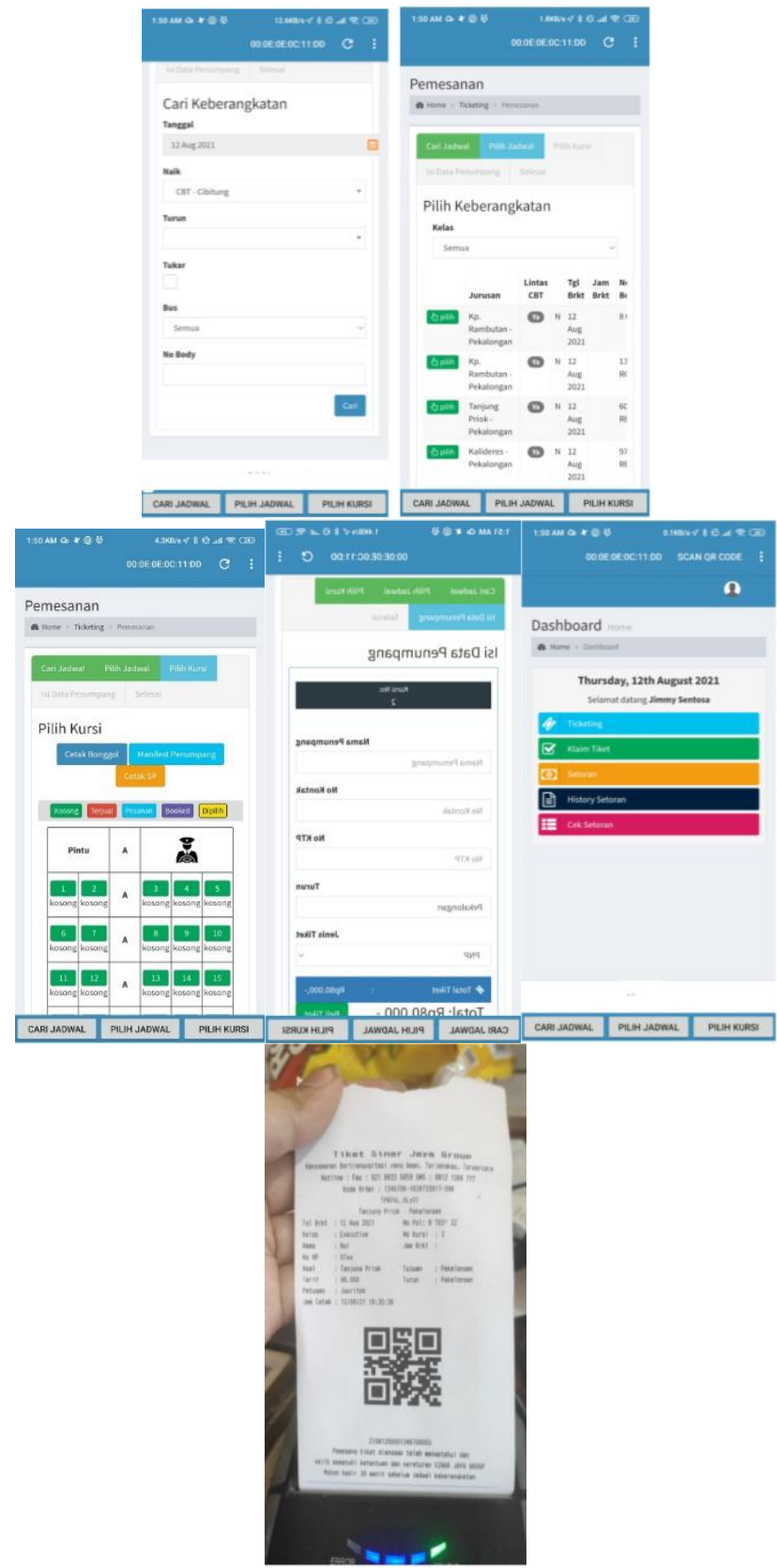

Fig. 5. Result of program

An API will be designed which has the following scheme to make sales

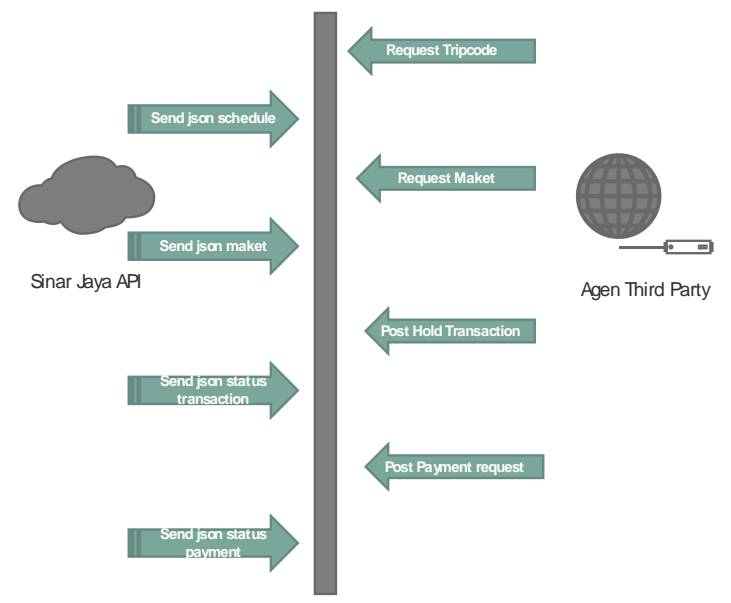

Fig. 6. API Process 
Table 5. E-Ticketing Api Method

\begin{tabular}{|l|l|l|}
\hline Method Description & Jenis Method & End Point \\
\hline Method get jadwal & $G E T$ & /api/jadwal \\
\hline Method get denah maket & $G E T$ & /api/kursi \\
\hline Method hold transaction & $P U T$ & /api/tiket \\
\hline Method payment & $P O S T$ & /api/payment \\
\hline
\end{tabular}

\section{CONCLUSION}

From this research, the following conclusions can be drawn: 1. Development of the e-ticketing system of PT. Sinar Jaya Megah Langgeng can be done using the SCRUM method. This study uses 3 product backlogs with each product backlog being carried out in one sprint duration. During the development stage, the development team used the Trello application as a project management application and for the deployment process, the author used the GIT application. With this application, the product owner can monitor the performance of the SCRUM team and the SCRUM master can see problems if there are tasks that are past the deadline. The author uses his own human resources consisting of one product owner, namely the author himself, one SCRUM master, two backend developers, two frontend developers, one mobile developer, one UX designer and one tester in system development.

2. To support the planning carried out in this research, all needs and goals must be understood by the SCRUM team. Needs analysis with user stories is quite helpful because the purpose of the application can be seen from there. Daily scrum meetings must always be held to monitor the performance of the SCRUM team and daily scrum meetings will minimize obstacles in the work because things that slow down can be analyzed by the SCRUM master to be minimized. The daily scrum meeting must run effectively with a duration of around 15 minutes so that the time used can be focused on project development. A sprint retrospective at the end of the sprint also needs to be done to analyze problems that arose during the previous sprint to be able to work on the next sprint better. The product owner's ability to seek information and liaise with stakeholders by conveying ideas and confirming needs during sprint work are skills that are needed to achieve increments.

\section{ACKNOWLEDGMENT}

To implement SCRUM in software development requires commitment and responsibility and the product owner must know the capabilities of everyone in the development team. During the sprint review process, the most effective way to determine whether a sprint was successful or not is to involve the user directly. So that users can provide suggestions or input for the features being worked on.

For further research, it is expected to take user subjects who have many wishes and comments and can answer any plans that can be used to minimize risk and whether development techniques using SCRUM can deal with such stakeholder characteristics.

\section{REFERENCES}

[1] Biehl, Matthias. 2015. RESTful API Design (API-University Series). CreateSpace Independent Publishing PlatformJ. Clerk Maxwell, A Treatise on Electricity and Magnetism, 3rd ed., vol. 2. Oxford: Clarendon, 1892, pp.68-73.

[2] Doglio, F. 2018. REST API Development with Node.js. Canelones: Apress.

[3] Fauziah, Della, Fajar Pradana dan Achmad Arwan. 2019. Pengembangan Aplikasi Pemesanan Tiket Travel Berbasis Web dengan Optimasi Jalur Penjemputan Penumpang. Jurnal Pengembangan Teknologi Informasi dan Ilmu KomputerK. Elissa, "Title of paper if known," unpublished.

[4] Ibrahim, Ahmed K. dan Azman B Ta'a. 2015. Mobile - Based Bus Ticketing System in Iraq. European Journal of Computer Science and Information Technology.

[5] Komala, Bienderil dan Achmad Kodar. 2018. Model Reservasi Massage Berbasis Website Menggunakan Algoritma FIFO dengan Metode Scrum. Jurnal Rekayasa Sistem dan Teknologi Informasi (RESTI).

[6] Kusuma, Des Chandra. 2017. Menjadi Kaya di Bisnis ECommerce. PT Gramedia Pustaka Utama.

[7] Law, Risal. 2015. Mari Belajar Pemrograman Berorientasi Objek menggunakan Visual C\# 6.0. Smashwords

[8] Mahalakshmi, M, dan DR. M. Sundararajan. 2013. Traditional SDLC vs Scrum Methodology. International Journal of Emerging Technology and Advanced Engineering

[9] McLeod, Raymond, Jr. 2010. Management Information System. Prentice Hall

[10] Mitchell, Lorna J. 2013. PHP Web Service. O'Reilly. Sebastopol.

[11] Naila, Ajith dan Muhammad Murshid M.A.. 2020. Smart Bus Ticketing System. International Research Journal of Engineering and Technology (IRJET)

[12] Oloyede, M.O, Alaya S.M dan Alaya S.M. 2014. Development of an Online Bus Ticket Reservation System for a Transportation Service in Nigeria. Computer Engineering and Intelligent Systems

[13] Permana, Putu Adi Guna. 2015. Scrum Method Implementation in a Software Development Project Management. International Journal of Advanced Computer Science and Applications

[14] Prasanna, K.Laxmi Sai, K.Shivani, N.Vaishnavi, Ms.P R Anisha, Dr.B V Ramana Murthy, dan Mr.C Kishor Kumar Reddy. 2019. Bus Reservation System. Global Journal of Engineering Science and Researches

[15] Raharjana, Indra Kharisma. 2017. Pengembangan Sistem Informasi Menggunakan Metodologi Agile. Deepublish

[16] Saputra, Agus. 2014. API Developer Buku Sakti Para Pengembang Web. CV Asfa Solution

[17] Satpathy, 2017, A Guide to the Scrum Body Of Knowledge (SBOK ${ }^{\mathrm{TM}}$ Guide), Arizona: SCRUMstudy ${ }^{\mathrm{TM}}$, a brand of VMEdu, Inc..

[18] Septian, Oky. 2019. Analisa Perancangan Sistem Informasi Pemesanan Tiket Museum Online di DKI Jakarta Berbasis Web. Jurnal Sistem Informasi, Teknologi Informasi dan Komputer

[19] Suryawan, I Gede Totok dan Ary Wira Andika. 2018. Implementasi SCRUM Model Development pada Rezvac Cloud Reservation dan Payment System. Prosiding: Siniesa

[20] Sutherland, Jeff. 2017. SCRUM: Meningkatkan Produktivitas Dua Kali Lipat dalam Waktu Setengahnya Saja. Bentang Pustaka

[21] Wahyudi. 2020. Pengembangan Aplikasi Sistem E-ticketing Konser Musik dengan Seating Number pada Website Motikdong.com. Jurnal Teknik Informatika (JIKA)

[22] Wardah, Neli Nailul. 2019. E-ticket PO. Bus Laju Prima Serang. Jurnal SITUSTIKA Volume 3

[23] Woodward, Elizabeth, Steffan Surdek, dan Matthew Ganis. 2010. A Practical Guide to Distributed Scrum (IBM Press) 1st Edition. IBM Press [24] Zonyfar, C., Maharina, Zayn, M. \& Barack, E., 2020. Student Enrollment: Data Mining Using Naïve Bayes Algorithm. Journal of Advanced Research in Dynamical and Control Systems, pp. 1077-1083.

[25] C. Zonyfar, S. Sihabudin, and A. Khusaeri, "Peningkatan Kemampuan Siswa dalam Memanfaatkan Sumber Belajar di Internet Melalui Sosialisasi Edukasi Internet Cerdas, Sehat, dan Aman", tribhakti, vol. 1, no. 1, pp. 17-20, Dec. 2019. 